\title{
Identifikasi Level Berpikir Kreatif Siswa dalam Menyelesaikan Soal Cerita Open Ended pada Materi SPLTV
}

\author{
Herman Shalahuddin ${ }^{1}$, Hery Susanto ${ }^{1}$, I Nengah Parta ${ }^{1}$ \\ ${ }^{1}$ Pendidikan Matematika-Universitas Negeri Malang
}

\section{INFO ARTIKEI}

\section{Riwayat Artikel:}

Diterima: 20-01-2019

Disetujui: 15-02-2019

\section{Kata kunci: \\ level of creative thinking; level berpikir kreatif; open ended}

\section{Alamat Korespondensi: \\ Herman Shalahuddin \\ Pendidikan Matematika \\ Universitas Negeri Malang \\ Jalan Semarang 5 Malang \\ E-mail: hshalahudddin@gmail.com}

\section{ABSTRAK}

Abstract: The purpose of this study was to identify the level of students' creative thinking skills in solving open-ended story problems in SPLTV material. The study was conducted by giving open ended story matter problems to SPLTV material to 34 high school students in class X. The results of data analysis showed that the level of creative thinking of students at the very creative level was 3 students, the creative level was 14 students, the level was quite creative as many as 3 students, the level was less creative as many as 14 students.

\begin{abstract}
Abstrak: Tujuan penelitian ini untuk mengidentifikasi level kemampuan berpikir kreatif siswa menyelesaikan soal cerita open ended pada materi SPLTV. Penelitian dilakukan dengan memberikan masalah soal cerita open ended pada materi SPLTV kepada 34 siswa kelas X SMA. Hasil analisis data yang diperoleh bahwa level berpikir kreatif siswa pada level sangat kreatif sebanyak 3 siswa, level kreatif sebanyak 14 siswa, level cukup kreatif sebanyak 3 siswa, level kurang kreatif sebanyak 14 siswa.
\end{abstract}

Beberapa tahun terakhir menunjukkan adanya penurunan minat belajar matematika ketika siswa sedang berada di kelas. Seringkali peneliti menemukan dan menjumpai ada gejala permasalahan ketika pembelajaran matematika berlangsung. Berdasarkan gejala yang sering dijumpai tersebut, peneliti menyusun rencana diagnosis awal tentang kemampuan berpikir kreatif siswa. Lebih jauh dalam menyikapi permasalahan tersebut, peneliti ingin meneliti dengan pendekatan pembelajaran yang tepat. Hal ini peneliti lakukan untuk mengetahui lebih mendalam tentang fakta kejadian tersebut. Berdasarkan hasil diskusi dan wawancara terhadap guru matematika Bapak Ahmad Rif'an Maulana tanggal 7 Agustus 2018, minat dan hasil belajar matematika menunjukkan hasil yang rendah. Permasalahan yang sering muncul di SMA, seperti adanya kesalahan konsep matematika yang mereka yakini benar pada jenjang sebelumnya di tingkat SMP atau MTs. Contoh kesalahan yang sering terjadi adalah ketika memisalkan variabel pada materi persamaan linier dua variabel. Misal kasus harga buah, harusnya $x$ menunjukkan harga jeruk dalam satuan kilogram tapi banyak yang menuliskan $x$ menunjukkan jeruk. Contoh kasus misalkan $2 x=8$. Harusnya $x=\frac{8}{2}$ tetapi masih banyak yang menjawab $x=8-2$. Hal ini sering terjadi dikarenakan karena kesalahan pemahaman dan dianggap sebagai pindah ruas.

Permasalahan lain muncul adanya kesulitan dalam memahami soal cerita terkait dengan masalah kontekstual sehingga tidak mengerti maksud kalimat soal tersebut. Secara umum, permasalahan yang terjadi sebenarnya dapat diselesaikan dengan mendiagnosis kesulitan siswa ketika belajar materi matematika. Selama ini guru hanya memberikan soal yang masih bersifat rutin, artinya cara menyelesaikannya dengan menggunakan rumus yang telah dipelajari. Tentu akan berbeda jika guru memberikan soal atau permasalahan yang bersifat non rutin. Dipastikan ketika membelajarkan matematika permasalahan non rutin akan memengaruhi kemampuan berpikir kreatif siswa. Hasilnya tentu akan rendah karena pendekatan pembelajaran untuk menyelesaikan masalah non rutin jarang dikembangkan di sekolah. Karena hal ini jarang sekali diajarkan kepada siswa dengan alasan waktu yang terbatas.

Pada saat kegiatan pembelajaran matematika seorang guru berharap siswanya memiliki kemampuan berpikir kritis, logis, dan bernalar. Melalui kemampuan ini diharapkan siswa mampu mengembangkan ide yang telah dimiliki. Hal ini bertujuan agar setiap siswa mampu menyelesaikan masalah yang dihadapi pada saat kegiatan pembelajaran berlangsung. Fokus penelitian ini terbatas kemampuan berpikir kreatif siswa. Ketika belajar matematika, aktivitas seseorang yang belajar sebagian besar adalah berpikir. Menurut (Noer, 2011) kemampuan berpikir kreatif matematis siswa yang belajar berbasis masalah open ended hasilnya lebih baik dibandingkan konvensional. (Firdaus, As'ari, \& Qohar, 2016) menyatakan kemampuan berpikir kreatif matematis siswa dapat ditingkatkan dengan pendekatan open ended pada materi SPLDV. Menurut (Istianah, 2013) dengan pendekatan MEAs 
kemampuan berpikir kreatif jauh lebih baik disbanding pembelajaran biasa. Hal yang senada menurut (Faridah, Isrok'atun, \& Aeni, 2016) kemampuan berpikir kreatif matematis siswa dapat ditingkatkan menggunakan pendekatan open ended serta lebih baik daripada konvensional, kepercayaan diri siswa pun meningkat. Di sisi lain menurut (Birgili, 2015) mengemukakan bahwa PBL mampu meningkatkan kemampuan berpikir kreatif dan kritis siswa. Berdasarkan hasil penelitian (Sul'an, 2017) bahwa pembelajaran melalui open ended menggunakan berpikir kreatif menjadikan sikap siswa terhadap matematika sangat positif.

Untuk menghadapi persoalan open ended siswa memerlukan pengembangan metode, cara, atau pendekatan agar bervariasi ketika mencari, memperoleh jawaban benar. Kegiatan berpikir kreatif dan pola pikir dapat dibantu dengan mengembangkan pembelajaran open ended. Disisi lain juga mampu memberi kesempatan siswa untuk investigasi bermacam strategi, cara yang sesuai dengan kemampuan elaborasinya. Menurut (Mahmudi, 2008) aspek keterbukaan dalam open ended diklasifikasikan tiga tipe, yaitu (1) proses penyelesaian yang terbuka, cara penyelesaiannya beragam, (2) hasil akhirnya terbuka, yakni memiliki banyak jawaban benar, dan (3) pengembangan lanjutan terbuka, setelah siswa menyelesaikan masalah, mereka dapat mengembangkan soal baru, mengubah syarat, kondisi soal yang diselesaikan. Dimensi yang dapat dilihat guru terhadap siswa untuk mengetahui berpikir kreatif atau tidak, di antaranya (a) siswa peka terhadap masalah, (b) fleksibel dalam berpikir, (c) menciptakan ide baru yang berguna, (d) orisinalitas dalam berpikir, dan (e) merumuskan proses penyelesaian dengan lancar, kreatif, dan sistematis.

Komponen pemecahan masalah matematika dengan berpikir kreatif meliputi fluency, flexibility, dan novelty (Siswono, 2011). Fluency, siswa dapat menghasilkan banyak solusi dalam menyelesaikan masalah. Flexibility, siswa mampu menyelesaikan masalah dengan cara atau metode yang berbeda. Novelty siswa menemukan solusi baru dan tidak lazim yang digunakan pada tingkat kemampuan yang sama. (Siswono, 2011) menyatakan level berpikir kreatif untuk menyelesaikan ada lima seperti tampak pada tabel 1 .

Tabel 1. Level Kemampuan Berpikir Kreatif

\begin{tabular}{ccccc}
\hline Level & Fluency & Flexibility & Novelty & Keterangan \\
\hline 4 & $\sqrt{ }$ & $\sqrt{ }$ & $\sqrt{ }$ & Sangat Kreatif \\
& - & $\sqrt{ }$ & $\sqrt{ }$ & Sangat Kreatif \\
3 & $\sqrt{ }$ & - & $\sqrt{ }$ & Kreatif \\
& $\sqrt{ }$ & $\sqrt{ }$ & - & Kreatif \\
2 & - & - & $\sqrt{ }$ & Cukup Kreatif \\
& - & $\sqrt{ }$ & - & Cukup Kreatif \\
1 & $\sqrt{ }$ & - & - & Kurang kreatif \\
0 & - & - & - & Tidak kreatif \\
\hline
\end{tabular}

\section{METODE}

Penelitian ini dilakukan dengan memberikan masalah berbentuk soal cerita open ended pada materi SPLTV. Tujuan memberikan masalah berbentuk soal cerita tersebut adalah untuk mengidentifikasi kemampuan siswa berdasarkan level berpikir kreatif menyelesaikan soal cerita open ended materi SPLTV berdasarkan aspek yaitu fluency, flexibility, dan novelty. Masalah yang diberikan terdiri dua soal cerita, satu soal untuk mengukur kemampuan berpikir kreatif dari aspek fluency, satu soal mengukur kemampuan berpikir kreatif dari aspek flexibility dan novelty. Responden penelitian ini siswa kelas X SMA sebanyak 34. Masalah soal cerita yang digunakan dalam penelitian ini telah divalidasi oleh seorang Dosen Universitas Negeri di wilayah Jawa Timur.

Setiap siswa diminta untuk menemukan kemungkinan jawaban yang memenuhi aspek fluency, flexibility, dan novelty dalam waktu 75 menit. Masalah yang diujikan ke siswa tampak pada gambar 1. Hasil pekerjaan siswa kemudian dikelompokkan serta dikodekan menjadi PD1-PD34. Untuk memudahkan pengaturan, data kemudian dianalisis dan dikelompokkan berdasarkan level kemampuan berpikir kreatif, meliputi (1) sangat kreatif, (2) kreatif, (3) cukup kreatif, (4) kurang kreatif, dan (5) tidak kreatif.

1. Ibu Yuli ingin membeli buah mangga. jeruk dan anggur. Masing-masing harga buah tersebut adalah sebagai berikut: Mangga Rp. 12.000,00/kg; Jeruk Rp. 8.000,00/kg; dan Anggur Rp. 20.000,00/kg. Jika uang yang dimiliki oleh Ibu Yuli sebesar Rp. 200.000,00 dan digunakan untuk membeli ketiga jenis buah tersebut dengan syarat uang itu harus habis, maka tentukan:

a. Berapa kg buah mangga, jeruk dan anggur yang dapat dibeli oleh ibu Yuli!

b. Buatlah model matematika dari permasalahan tersebut dalam bentuk sistem persamaan linier tiga variabel (SPLTV)!

2. Alex, Budi dan Hasan akan membeli sejumlah barang berupa topi, kaos dan tas. Alex membeli 2 topi, 3 kaos dan 1 tas seharga Rp. 400.000,00. Budi membeli 5 topi, 2 kaos dan 2 tas seharga Rp. 540.000,00. Sedangkan Hasan membeli 1 topi, 5 kaos dan 3 tas seharga Rp. 670.000,00. Tentukan himpunan penyelesaian dari sistem persamaan linier tiga variabel tersebut!

\section{Gambar 1. Tes Soal Cerita Open Ended Pada Materi SPLTV}

Setelah selesai mengerjakan, maka hasil pekerjaan siswa yang telah dikodekan PD1-PD34 tersebut kemudian dianalisis. Analisis tersebut dilakukan berdasarkan level berpikir kreatif berdasarkan kemampuan yang dimiliki ditinjau dari aspek fluency, flexibility, dan novelty. 


\section{HASIL}

Hasil pekerjaan siswa dikelompokkan berdasarkan level berpikir kreatif ditinjau dari aspek fluency, flexibility, dan novelty pada materi SPLTV. Berikut level berpikir kreatif siswa menyelesaikan soal cerita open ended materi SPLTV berdasarkan hasil tes yang ditunjukkan pada tabel 2 .

Tabel 2. Level Kemampuan Berpikir Kreatif Siswa Berdasarkan Hasil Tes

\begin{tabular}{ccc}
\hline No. Urut & Nama & Keterangan \\
\hline 1 & PD-1 & Kreatif \\
2 & PD-2 & Kurang Kreatif \\
3 & PD-3 & Cukup Kreatif \\
4 & PD-4 & Kreatif \\
5 & PD-5 & Kurang Kreatif \\
6 & PD-6 & Cukup Kreatif \\
7 & PD-7 & Sangat Kreatif \\
8 & PD-8 & Sangat Kreatif \\
9 & PD-9 & Kurang Kreatif \\
10 & PD-10 & Kurang Kreatif \\
11 & PD-11 & Kreatif \\
12 & PD-12 & Kurang Kreatif \\
13 & PD-13 & Kreatif \\
14 & PD-14 & Kurang Kreatif \\
15 & PD-15 & Kreatif \\
16 & PD-16 & Cukup Kreatif \\
17 & PD-17 & Kurang Kreatif \\
\hline
\end{tabular}

\begin{tabular}{ccc}
\hline No. Urut & Nama & Keterangan \\
\hline 18 & PD-18 & Kreatif \\
19 & PD-19 & Kurang Kreatif \\
20 & PD-20 & Kurang Kreatif \\
21 & PD-21 & Kreatif \\
22 & PD-22 & Kreatif \\
23 & PD-23 & Kreatif \\
24 & PD-24 & Kreatif \\
25 & PD-25 & Kreatif \\
26 & PD-26 & Kreatif \\
27 & PD-27 & Kurang Kreatif \\
28 & PD-28 & Kurang Kreatif \\
29 & PD-29 & Kurang Kreatif \\
30 & PD-30 & Sangat Kreatif \\
31 & PD-31 & Kurang Kreatif \\
32 & PD-32 & Kreatif \\
33 & PD-33 & Kurang Kreatif \\
34 & PD-34 & Kurang Kreatif \\
\hline
\end{tabular}

Berdasarkan pada tabel di atas terlihat bahwa kemampuan berpikir kreatif level sangat kreatif sebanyak tiga siswa, level kreatif sebanyak 14 siswa, level cukup kreatif sebanyak tiga siswa, level kurang kreatif sebanyak 14 siswa dan siswa pada level tidak kreatif tidak ada. Berikut hasil rekapitulasi jumlah siswa berdasarkan level berpikir kreatif setelah mengerjakan tes soal cerita open ended yang peneliti sajikan pada Tabel 3.

Tabel 3. Jumlah Siswa Berdasarkan Level Kemampuan Berpikir Kreatif

\begin{tabular}{lc}
\hline \multicolumn{1}{c}{ Level } & Jumlah Siswa \\
\hline Sangat Kreatif & 3 \\
Kreatif & 14 \\
Cukup Kreatif & 3 \\
Kurang Kreatif & 14 \\
Tidak Kreatif & 0 \\
\hline
\end{tabular}

Dalam kegiatan pembelajaran, siswa mengidentifikasi kemungkinan jawaban lebih dari satu. Siswa diminta untuk menentukan kemungkinan banyaknya mangga, jeruk, dan anggur dalam satuan kilogram yang dapat dibeli jika tersedia uang sebesar Rp.200.000,000 dan memiliki syarat bahwa uang tersebut harus dihabiskan. Kemudian siswa diminta untuk menentukan dan membuat model SPLTV yang dapat dibuat setelah menemukan komposisi banyaknya mangga, jeruk, dan anggur yang telah ditemukan jawabannya. Berikut hasil pekerjaan siswa menyelesaikan soal cerita open ended materi SPLTV yang peneliti sajikan pada gambar 2.

Pada gambar 2 tampak bahwa salah satu siswa telah mampu menentukan banyaknya mangga, jeruk, dan anggur yang dapat dibeli dengan menggunakan uang sebesar RP.200.00,00. Jawaban tersebut seperti yang ditunjukkan dalam bentuk tabel dengan banyaknya jawaban ada 10 kemungkinan. Selain itu tampak juga bahwa siswa telah mampu menentukan dan membuat model matematika sistem persamaan linier tiga variabel sebanyak 10 jawaban yang berbeda. Mengacu jawaban yang terlihat pada gambar 2 tampak bahwa siswa telah mampu menemukan lebih dari satu jawaban benar sehingga siswa telah memenuhi aspek berpikir kreatif yaitu fluency atau kelancaran. Selain aspek fluency siswa masih dituntut untuk mampu menyelesaikan SPLTV dengan menggunakan cara yang telah mereka ketahui. Berikut hasil pekerjaan siswa dalam menyelesaikan masalah sistem persamaan linier tiga variabel yang tampak pada Gambar 3. 

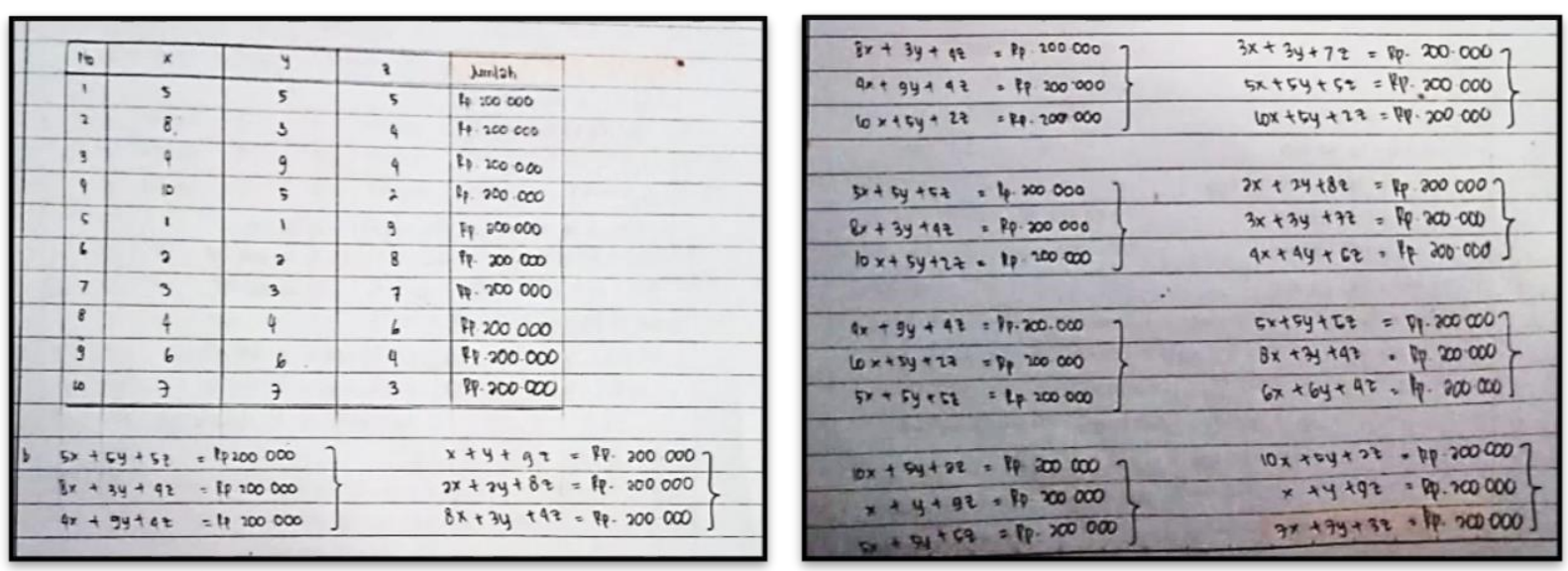

Gambar 2. Hasil Jawaban Siswa Berdasarkan Aspek Fluency
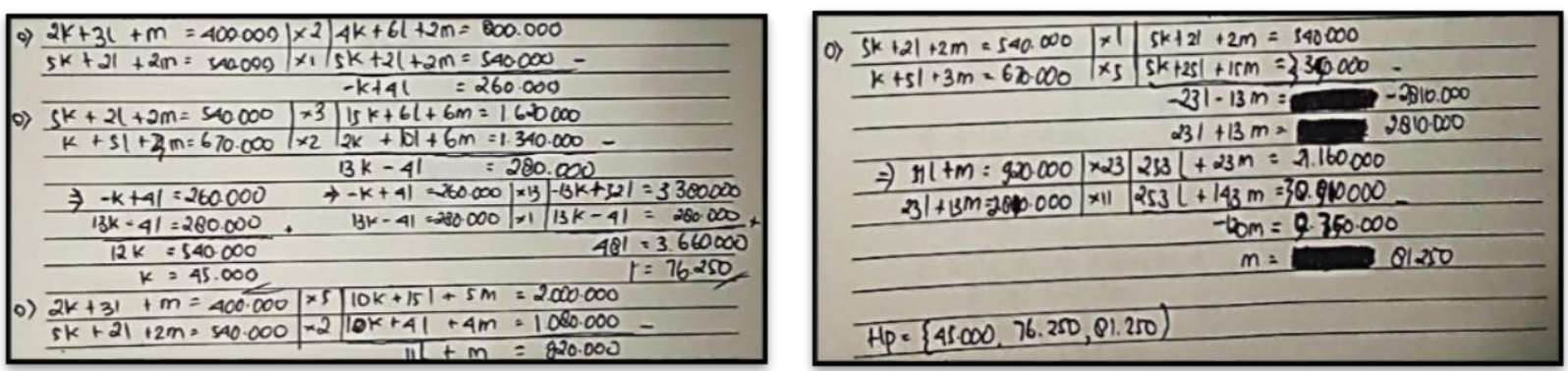

Gambar 3. Hasil Jawaban Siswa dengan Metode Eliminasi
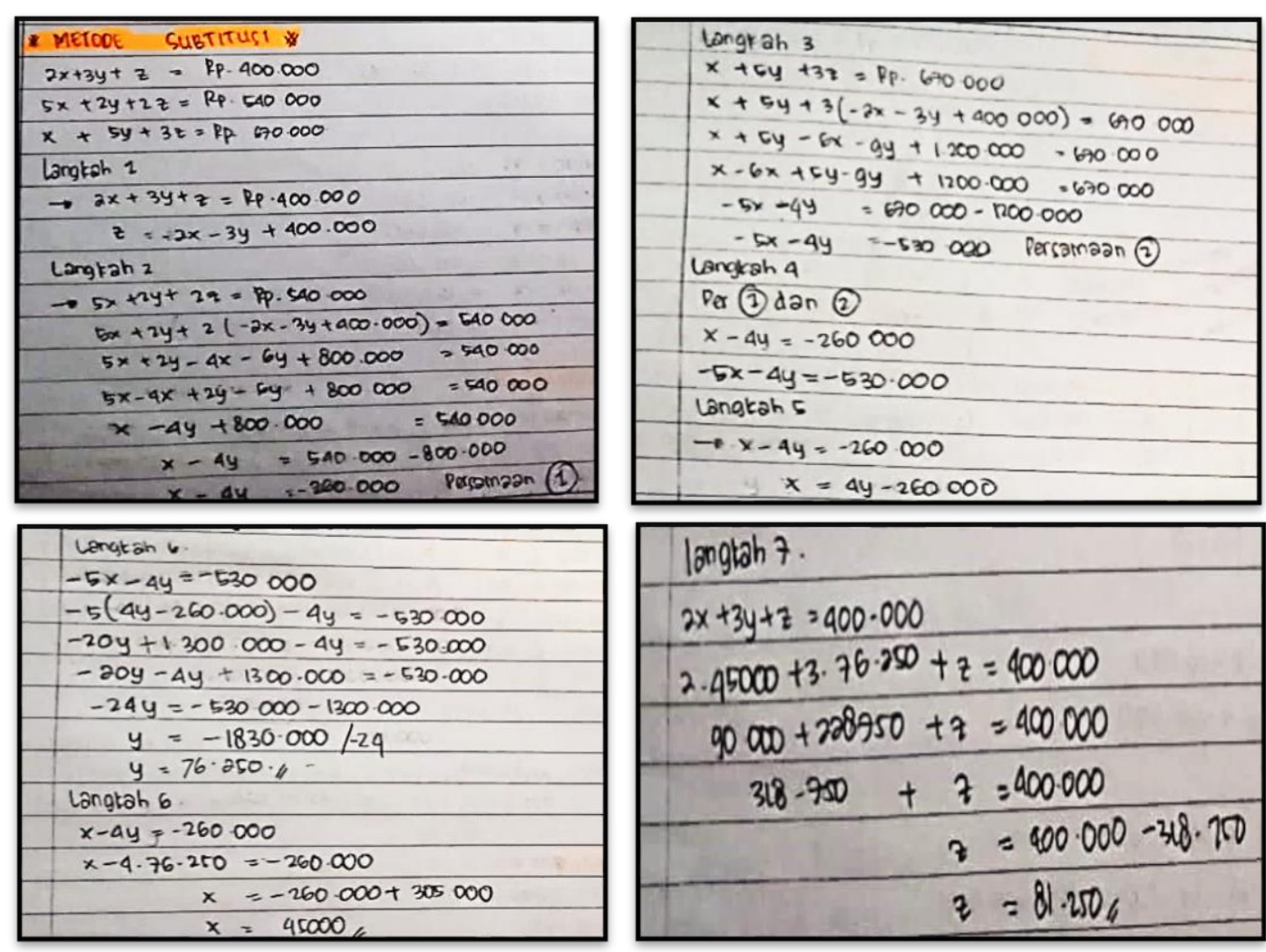

$\begin{aligned} & \text { longtoh } z . \\ & 2 x+3 y+z=400.000 \\ & 2.45000+3.76 .250+z=400000 \\ & 90000+228750+z=400000 \\ & 318.750+z=400.000 \\ & z=800.000-318.750 \\ & z=81.250\end{aligned}$

Gambar 4. Hasil Jawaban Siswa dengan Metode Substitusi 
Pada Gambar 3 di atas menunjukkan bahwa siswa telah mampu menyelesaikan sistem persamaan linier dengan menggunakan metode eliminasi. Hasil jawaban yang ditemukan siswa tersebut dalam menentukan harga 1 topi, 1 kaos, dan 1 tas masing-masing adalah Rp.45.000,00, Rp.76.250,00, dan Rp.81.250,00 yang merupakan himpunan penyelesaian dalam permasalahan yang diberikan oleh peneliti. Selain dengan menggunakan metode eliminasi, siswa juga menggunakan metode lain sebagaimana yang tampak pada Gambar 4.

Pada gambar 4 tersebut di atas menunjukkan bahwa siswa tersebut telah mampu menemukan metode lain untuk menyelesaikan SPLTV, yaitu metode substitusi. Hasil jawaban yang ditemukan siswa pun sama dalam menentukan harga 1 topi, 1 kaos, dan 1 tas masing-masing adalah Rp.45.000,00, Rp.76.250,00, dan Rp.81.250,00 yang merupakan himpunan penyelesaian. Selain menggunakan metode eliminasi dan subtitusi ternyata siswa juga mampu memberikan alternatif metode yang lain. Metode yang digunakan untuk menentukan HP atau solusi SPLTV tersebut adalah metode campuran. Penyelesaian dengan metode campuran tampak pada Gambar 5.
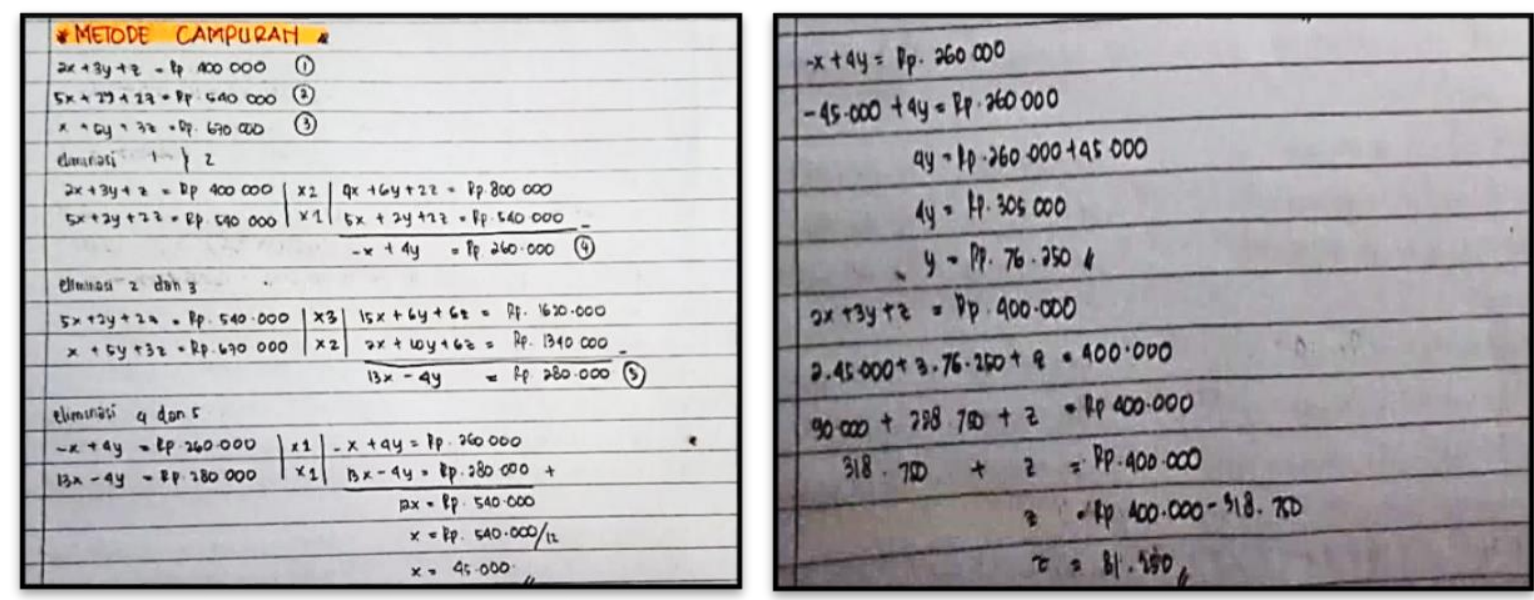

Gambar 5. Hasil Jawaban Siswa dengan Metode Campuran

Berdasarkan gambar 3, 4, dan 5 jawaban yang diberikan siswa tersebut menunjukkan hasil jawaban yang sama. Ditinjau dari aspek berpikir kreatif maka siswa tersebut memenuhi aspek flexibility. Hal ini dikarenakan siswa tersebut telah mampu memberikan alternatif jawaban menggunakan metode lebih dari 2.

Selain menggunakan metode eliminasi, subtitusi, dan campuran siswa dituntut untuk menemukan metode yang lain. Metode tersebut tidak diajarkan didalam kegiatan belajar mengajar di kelas. Hal ini peneliti lakukan untuk mengetahui kemampuan berpikir kreatif siswa ditinjau dari aspek novelty atau kebaruan. Ternyata setelah mencari alternatif metode melalui searching di internet, bertanya kepada guru atau orang lain selain peneliti mereka menemukan informasi tentang metode determinan seperti Gambar 6.
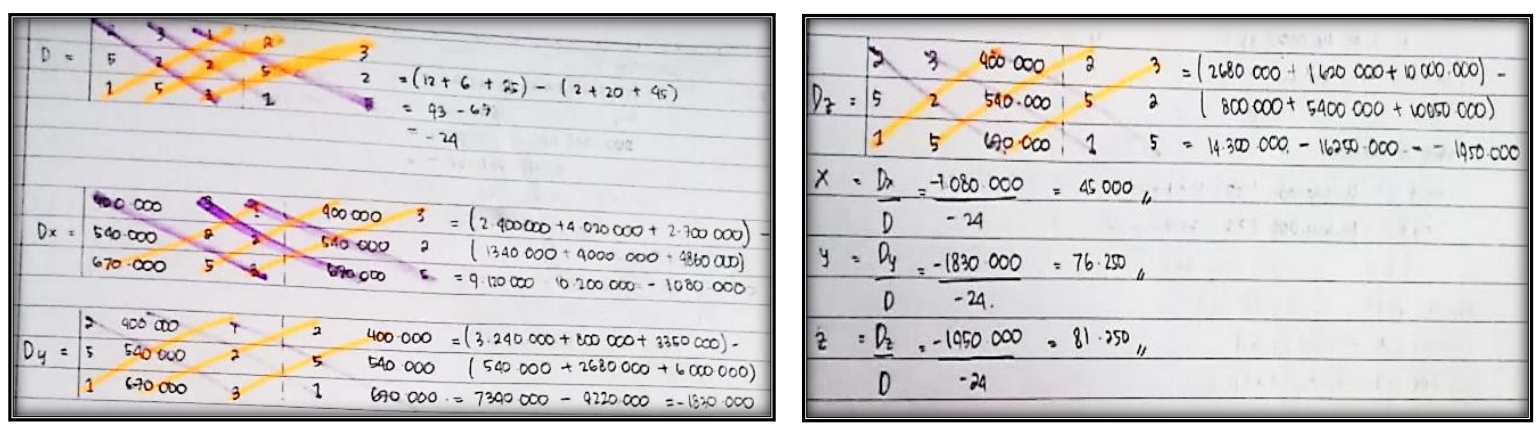

\section{Gambar 6. Hasil Jawaban Siswa dengan Metode Determinan}

Berdasarkan gambar 6 di atas diperoleh hasil yang sama untuk penyelesaian SPLTV menggunakan metode determinan. Hasil penyelesaian tersebut untuk harga 1 topi, 1 kaos, dan 1 tas berturut-turut adalah Rp 45.000,00, Rp.76.250,00, dan Rp $81.250,00$. 


\section{PEMBAHASAN}

Penelitian ini menggunakan masalah kontekstual berupa soal cerita open ended pada materi SPLTV. Peneliti menyajikan masalah matematika berdasarkan konteks kehidupan sehari-hari. Setelah itu mendesain soal tersebut agar memiliki jawaban lebih dari satu. Fokus masalah yang dibuat peneliti berkaitan dengan sistem persamaan linier tiga variabel. Kemudian siswa menjawab dua permasalahan yang terdiri dari masalah non rutin dan masalah rutin. Dari masalah non rutin diharapkan siswa mampu menemukan jawaban lebih dari satu dan benar. Sementara itu, dari permasalahan yang bersifat rutin diharapkan siswa mampu untuk menyelesaikan permasalahan tersebut dengan menggunakan cara lebih dari satu atau ada satu cara baru yang belum pernah diajarkan dalam kegiatan pembelajaran di kelas atau mereka mampu menemukan metode tersebut secara mandiri. Masalah non rutin dan rutin tersebut diberikan dengan tujuan untuk melatih berpikir kreatif siswa dalam matematika. (Mann, 2005) menyatakan pemberian pengalaman yang banyak dalam menyelesaikan masalah merupakan cara signifikan untuk membangun kreativitas matematika siswa. Selain itu, (Lince, 2016) menyatakan bahwa berdasarkan hasil penelitiannya diperoleh kesimpulan (a) kemampuan berpikir kreatif matematika siswa meningkat dengan menerima model pembelajaran NHT lebih baik dari siswa pembelajarannya konvensional dan (b) belajar dengan NHT lebih cocok untuk meningkatkan kemampuan siswa untuk berpikir kreatif matematis.

(Yusnaeni, dkk, 2017) menyimpulkan model pembelajaran SSCS + MS memiliki potensi untuk meningkatkan kemampuan berpikir kreatif dari kemampuan akademik rendah melebihi siswa kemampuan akademik tinggi. Model pembelajaran ini mampu meningkatkan kualitas pembelajaran di kelas karena dapat menumbuhkan kesadaran belajar dan kesadaran berpikir siswa kemampuan akademik rendah. Model pembelajaran ini sangat berguna untuk diterapkan di sekolah-sekolah yang mayoritas siswanya memiliki kemampuan rendah. (Sriwongchai, dkk, 2015) menyebutkan ada enam langkah kegiatan pembelajaran yang digunakan mendorong kemampuan siswa berkonsentrasi. Konsentrasi itu untuk mencari tahu jawaban yang benar dari masalah, dan mendorong siswa berpikir untuk menemukan solusi melalui masalah terbuka atau berpikir divergen secara terus menerus. Langkah tersebut, meliputi (1) meninjau pengetahuan sebelumnya, (2) investigasi pengetahuan baru, (3) kesimpulan konseptual, (4) berlatih pengetahuan baru, (5) penerapan pengetahuan, dan (6) evaluasi pembelajaran. Hasil penelitian (Oncu, 2016) menunjukkan bahwa berdasarkan kreativitas kegiatan pendidikan memiliki dampak positif pada pemikiran kreatif dan divergen, yang diukur dengan Torrance test of creative thinking (TTCT), mendukung untuk meningkatkan berpikir kreatif. Senada dengan hasil penelitian tindakan kelas (Widiana \& Jampel, 2016), disarankan bahwa (1) kepada guru untuk menggunakan pendekatan pengajaran multi-intelijen dibantu salah satu model pengajaran yang inovatif dalam upaya meningkatkan siswa keterampilan berpikir kreatif, (2) guru hendaknya memperhatikan kegiatan refleksi pada saat kegiatan pembelajaran dan mengetahui karakteristik sekolah, kelas dan siswa. Menurut (Ayllón, dkk, 2016), misi prioritas guru adalah untuk mengidentifikasi dan mengembangkan kreativitas, dan mereka perlu lingkungan yang memadai untuk belajar kreatif. Pembelajaran tersebut membutuhkan bahan asosiasi dan ide-ide fleksibel dan memiliki metodologi tidak langsung, pembinaan dan imajinatif serta menyenangkan. Salah satu kekhawatiran terbesar guru adalah untuk mencapai kegiatan belajar mengajar matematika perlu mengembangkan pemikiran logis siswa sebagai sarana konstruktivis dan sesuai dengan metodologi sehingga mampu membuat alat matematika untuk diterapkan dalam kehidupan sehari-hari.

Belajar melalui pendekatan open-ended lebih baik dan kemampuan berpikir kreatif matematika siswa menjadi meningkat meskipun kategori sekolah yang berbeda. Lebih lanjut, hasil belajar siswa melalui pendekatan open-ended hasilnya lebih baik dibandingkan dengan belajar konvensional (Fatah, dkk, 2016). (Yildiz, dkk, 2017) mengungkapkan bahwa guru yang mengajar menggunakan perangkat lunak yang dinamis memungkinkan siswa untuk belajar dengan mengalami proses visualisasi. Siswa tidak hanya membuat pengamatan, tetapi mereka juga memiliki kemampuan untuk mengukur, membuat perbandingan dan untuk mengubah bentuk sehingga kemampuan berpikir kreatif pun dapat terwujud. Di sisi lain, (Cenberci, 2018) menyatakan guru matematika dapat mengembangkan kecenderungan pemikiran kreatif mereka, mereka dapat berbicara dengan bebas dan tidak dihakimi, serta memunculkan ide berpikir kreatif. Cara yang dapat digunakan, meliputi (1) harus dipastikan mereka dapat memperbaiki dan meningkatkan kesadaran diri tentang pendidikan Matematika dan (2) setelah menerima penjelasan, lingkungan di mana mereka mempersiapkan materi untuk studi proyek yang berhubungan dengan mata pelajaran harus dibuat, dan kreativitas mereka harus dikembangkan.

(Tandiseru, 2015) menyatakan bahwa keterampilan berpikir kreatif melalui CTS mampu meningkatkan tiga kali dari Prior Mathematical Knowledge Test antara siswa yang mendapat model LC-BMHLM ketika belajar dengan siswa yang mendapatkan pembelajaran biasa. (Kadir, dkk, 2017) menyatakan kemampuan Mathematical Creative Thinking Skills melalui pembelajaran matematika menggunakan Open- Inquiry Approach mencapai tingkat kategori baik dan meningkat secara signifikan. (Al-Mahasneh, 2018) dan menyatakan dan merekomendasikan program review untuk persiapan dan pelatihan guru, dan dimasukkannya strategi mekanik. (Lee, dkk, 2003) menyatakan bahwa pembelajaran yang didasarkan pada pendekatan open ended pengembangan pemikiran kreatif, dan metode pengembangan siswa dalam rencana kegiatan pembelajaran. (Aktaş, 2016) dalam penelitiannya menyatakan bahwa konsepsi kreativitas guru dalam mengembangkan kemampuan berpikir kreatif siswa perlu di eksplorasi, misalnya melalui wawancara. Kemudian ia menyarankan observasi kelas harus dilakukan untuk menguji perbedaan apa yang guru katakan dan lakukan di dalam kelas. (Castro, dkk, 2018) mengungkapkan bahwa imajinasi adalah bagian dari kecerdasan kreatif dan memungkinkan siswa untuk membayangkan skenario matematis yang mungkin bermasalah itu dapat diatasi. Masalah harus digunakan untuk memverifikasi kemajuan belajar siswa yang dibuat sebagai sarana evaluasi, dan untuk mengukur latihan keterampilan dapat membantu siswa dalam menumbuhkan kreativitas pada matematika karena metode ini 
bukan hanya menerapkan dan berlatih algoritma yang disampaikan oleh guru, tetapi mendorong siswa untuk menantang masalah baru. Menurut (Fauzi, dkk, 2019) ada lima tahapan hierarki pemikiran belajar kreatif matematika, meliputi orientasi masalah, rencana pemecahan masalah, rencaana realisasi, penguasaan pengetahuan sebelumnya/konsep kreativitas matematika, dan evaluasi hasil yang diperoleh.

Peneliti meminta siswa untuk menyelesaikan masalah yang telah diberikan berdasarkan pengetahuan yang dimiliki sebelumnya atau materi prasyarat. Hal ini didukung oleh pendapat (Hudoyo, 2005) bahwa untuk menyelesaikan masalah matematika, siswa perlu prasyarat pengetahuan, ketrampilan dan pemahaman. Materi prasyarat juga dibutuhkan dalam belajar kreatif karena belajar kreatif tidak dapat dilaksanakan secara langsung, tetapi membutuhkan tahapan-tahapan. Dengan mengingatkan materi prasyarat merupakan salah salah satu bentuk dari tahap persiapan pada proses kreatif. Disamping itu peneliti berharap dengan memiliki kemampuan berpikir kreatif, siswa diharapkan mampu memecahkan masalah non rutin dan rutin. Aspek yang digunakan penelitian untuk mengetahui level kemampuan berpikir kreatif meliputi fluency, flexibility, dan novelty. (Hudoyo, 2005) menyatakan bahwa tujuan pembelajaran pada perencanaan pembelajaran melalui pemecahan masalah hendaknya siswa mampu menyelesaikan masalah yang tidak rutin. Penyampaian tujuan pembelajaran juga dapat menjelaskan pada siswa apa yang mereka lakukan pada saat pembelajaran dan menjadikan siswa fokus pada satu tujuan yang perlu capai. Tujuan pembelajaran adalah agar siswa tahu dengan jelas, mengapa partisipasi dalam pelajaran dibutuhkan dan mengetahui mereka dapat melakukan apa setelah selesai berperan serta.

\section{SIMPULAN}

Penelitian ini memberikan masalah soal cerita open ended pada materi SPLTV kepada 34 siswa kelas X SMA. Level berpikir kreatif menyelesaikan masalah dalam penelitian ini berdasarkan level berpikir kreatif pendapat Siswono (2011). Level kemampuan berpikir kreatif tersebut terbagi menjadi lima, yaitu level sangat kreatif, kreatif, cukup kreatif, kurang kreatif, dan tidak kreatif. Berdasarkan analisis data diperoleh informasi bahwa level berpikir kreatif siswa pada level sangat kreatif sebanyak tiga siswa, level kreatif sebanyak 14 siswa, level cukup kreatif sebanyak tiga siswa, level kurang kreatif sebanyak 14 siswa.

Semoga penelitian identifikasi level berpikir kreatif siswa menyelesaikan soal open ended pada materi SPLTV ada guna dan manfaatnya dalam dunia pendidikan khususnya bagi peneliti dapat meningkatkan kemampuan membuat artikel sebagai bentuk kegiatan pengembangan diri kedepannya. Segala bentuk kritik, saran, masukan yang konstruktif dari pembaca tetap kami harapkan dan kami terima dengan senang hati. Bagi sekolah yang kami pergunakan sebagai tempat penelitian, mudah-mudahan dapat membawa manfaat di dalam mengembangkan keterampilan siswa dalam mata pelajaran matematika sekaligus mampu untuk mengembangan kemampuan berpikir kreatif.

\section{DAFTAR RUJUKAN}

Aktaş, M. C. (2016). Turkish High School Teachers' Conceptions of Creativity in Mathematics. Journal of Education and Training Studies, 4(2), 42-52. https://doi.org/10.11114/jets.v4i2.1123

Al-Mahasneh, R. (2018). The Role of Teachers in Establishing an Attractive Environment to Develop the Creative Thinking among Basic Stage Students in the Schools of Tafilah Governorate According to their own Perspective. Journal of Curriculum and Teaching, 7(1), 206-221. https://doi.org/10.5430/jct.v7n1p206

Ayllón, M. F., Gómez, I. A., \& Claver, J. B. (2016). Mathematical Thinking and Creativity Through Mathematical Problem Posing and Solving. Propósitosy Representaciones, 4(1), 169-218. http://dx.doi.org/10.20511/pyr2016.v4n1.89

Birgili, B. (2015). Creative and Critical Thinking Skills in Problem Based Learning Environments. Journal of Gifted Education and Creativity, 2(2), 71-80. https://doi.org/10.18200/JGEDC.2015214253

Castro, A. M. T., Guerra, G. E. C, Brito, C. A. P., \& Chávez, T. G. A. (2018). Leisure Activities for The Development of Creative Intelligence in Mathematical Problem Solving. Journal of Technology and Science Education, 8(2), $126-131$. http://dx.doi.org/10.3926/jotse.412

Cenberci, S. (2018). The Investigation of the Creative Thinking Tendency of Prospective Mathematics Teachers in Terms of Different Variables. Journal of Education and Training Studies, 6(9), 78-85. https://doi.org/10.11114/jets.v6i9.3434

Faridah, N., Isrok'atun., \& Aeni, A. N. (2016). Pendekatan Open Ended untuk Meningkatkan Kemampuan Berpikir Kreatif Matematis dan Kepercayaan Diri Siswa. Jurnal Pena Ilmiah, 1(1), 1061-1070.

Fatah, A., Suryadi, D., Sabandar, J., \& Turmudi. (2016). Open-Ended Approach : An Effort In Cultivating Students’ Mathematical Creative Thinking Ability and Self-Esteem In Mathematics. Journal on Mathematics Education, 7(1), 1120. https://doi.org/10.22342/jme.7.1.2813.9-18

Fauzi, K. M. A., Dirgeyase, I. W., \& Priyatno, A. (2019). Building Learning Path of Mathematical Creative Thinking of Junior Students on Geometry Topics by Implementing Metacognitive Approach. International Education Studies, 12(2), 57-66. https://doi.org/10.5539/ies.v12n2p57

Firdaus., As'ari, A. R., \& Qohar, A. (2016). Meningkatkan Kemampuan Berpikir Kreatif Matematis Siswa SMA melalui Pembelajaran Open Ended pada Materi SPLDV. Jurnal Pendidikan: Teori, Penelitian, dan Pengembangan, 1(2), 227236.

Hudoyo, H. (2005). Pengembangan Kurikulum dan Pembelajaran Matematika. Malang: UM Press. 
Istianah, E. (2013). Meningkatkan Kemampuan Berpikir Kritis dan Kreatif Matematik dengan Pendekatan Model Eliciting Activities (MEAS) pada Siswa SMA. Infinity Journal, 2(1), 43-54.

Kadir., Lucyana., \& Satriawati, G. (2017). The Implementation of Open-Inquiry Approach to Improve Students' Learning Activities, Responses, and Mathematical. Journal on Mathematics Education, 8(1), 103-114.

Lince, R. (2016). Creative Thinking Ability to Increase Student Mathematical of Junior High School by Applying Models Numbered Heads Together. Journal of Education and Practice, 7(6), 206-212.

Mahmudi, A. (2008). Mengembangkan Soal Terbuka (Open-Ended Problem) dalam Pembelajaran Matematika. Retrieved from http://staffnew.uny.ac.id/upload/132240454/penelitian/Makalah+02+PIPM+2008+_Mengembangkan+Soal+Terbuka_.pdf

Noer, S. H. (2011). Kemampuan Berpikir Kreatif Matematis dan Pembelajaran Matematika Berbasis Masalah Open-Ended. Jurnal Pendidikan Matematika, 5(1), 104-111. DOI: https://doi.org/10.22342/jpm.5.1.824.

Oncu, E. C. (2016). Improved Creative Thinkers in a Class : A Model of Activity Based Tasks for Improving University Students' Creative Thinking Abilities. Educational Research and Reviews, 11(8), 517-522. https://doi.org/10.5897/ERR2015.2262

Siswono, T. Y. E. (2011). Level of Student's Creative Thinking in Classroom Mathematics. Educational Research and Reviews $6(7), 548-553$.

Sriwongchai, A., Jantharajit, N., \& Chookhampaeng, S. (2015). Developing the Mathematics Learning Management Model for Improving Creative Thinking In Thailand. International Education Studies, 8(11), 77-87. https://doi.org/10.5539/ies.v8n11p77

Sul'an. (2017). Penerapan Pembelajaran Pendekatan Open Ended dengan Menggunakan Berpikir Kreatif pada Materi Matriks bagi Siswa SMA Islam Kota Malang. Tesis tidak diterbitkan. Universitas Negeri Malang, Malang.

Tandiseru, S. R. (2015). The Effectiveness of Local Culture-Based Mathematical Heuristic-KR Learning towards Enhancing Student' s Creative Thinking Skill. Journal of Education and Practice, 6(12), 74-82.

Widiana, I. W., \& Jampel, I. N. (2016). Improving Students' Creative Thinking and Achievement through The Implementation of Multiple Intelligence Approach with Mind Mapping. International Journal of Evaluation and Research in Education, 5(3), 246-254.

Yildiz, A., Baltaci, S., \& Demir, B. K. (2017). Reflection on the Analytic Geometry Courses : The GeoGebra Software and its Effect on Creative Thinking. Universal Journal of Educational Research, 5(4), 620-630. https://doi.org/10.13189/ujer.2017.050411

Yusnaeni., Corebima, A. D., Susilo, H., \& Zubaidah, S. (2017). Creative Thinking of Low Academic Student Undergoing Search Solve Create and Share Learning Integrated with Metacognitive Strategy. International Journal of Instruction, $10(2), 245-262$. 